\title{
Scientific explanation of the composition and technological modes of manufacture of dairy ice cream with vegetable puree
}

\author{
Viktoriia Sapiga, Galyna Polischuk, Tetiana Osmak, \\ Artur Mykhalevych, Maksym Maslikov
}

National University of Food Technologies, Kyiv, Ukraine

\section{Keywords: \\ Ice cream \\ Vegetable \\ Puree \\ Pectin \\ Milk \\ Maturation}

Article history:

Received

30.01.2019

Received in revised

form 18.05.2019

Accepted

30.05.2019

\section{Corresponding author:}

Tetiana Osmak

E-mail:

osmaktg@ukr.net

\section{DOI:}

$10.24263 / 2310-$

1008-2019-7-1-10

\section{Abstract}

Introduction. The modern assortment of ice cream on milk base with vegetable fillers has been analyzed. The choice of vegetable raw material as a promising functional and technological ingredient in composition of milk ice cream is substantiated.

Materials and methods. Object of research - ice cream technology. The subject of the study - vegetable puree from beet and broccoli fresh and heat-treated, ice cream and milkvegetable blends. The cryoscopic temperature of the blends was determined with the aid of a measuring complex, dynamic viscosity by Geppler viscometer, resistance to melting - the melting time of hardened ice cream samples, the air bubbles size - the microscopy of soft ice cream samples in the chamber Goryaev, ice cream overrun - by the weight method.

Results and discussion. Scientifically confirmed the expediency of using in composition of the milk ice cream vegetable puree with a high content of soluble pectin due to thermoacid hydrolysis protopectin. The possibility of partial replacement of the stabilizer of the structure on pectin containing puree is established, which, in addition to the structural function, acts as a natural dye and a taste-aromatic ingredient, enriches the product with a complex of carbohydrates and minerals. By the magnitude of dynamic viscosity coefficient, rational regimes of maturating milkvegetable blends with different ratios between the milk and vegetable component were substantiated. It has been established that functional and technological vegetable puree in the amount of $10-20 \%$ practically does not affect the cryoscopic temperature of ice cream blends, which makes it possible to apply commonly accepted freeze modes to obtain a product of guaranteed quality.

Conclusions. A new kind of dairy ice cream with concentrate vegetable puree of high nutritional value can be recommended for widespread introduction in accordance with the classical technological scheme of production with refinement of maturating regimes. 


\section{Introduction}

At the present stage of development of the food industry, the production of food products enriched with biologically valuable components, with reduced fat content, is becoming increasingly relevant. Thanks to refreshing action, pleasant taste and high nutrition value, ice cream has become a daily product of mass consumption for children and adults. The assortment of frozen desserts on milk basis contains more than 1000 names, but in the domestic market practically there is no ice cream from vegetable raw materials. Vegetables give the product not only a pleasant original taste, but also have many beneficial properties.

It is known ice cream recipes on the basis of marinated ginger, with vegetable raw materials, in particular with mashed pumpkin, carrots, cucumbers, tomatoes. True exotic ice cream types for true gourmets are ice cream, made in France - with the taste of basil, onion, mustard, black pepper and cheese rockfor, as well as truffles and foie gras [1].

At the same time, table beet, which cultivated in Ukraine contains up to 6-12\% sucrose, as well as a significant amount of fructose, glucose, polysaccharides (pectin substances and fiber), organic acids (oxalic, apple, lemon), and by content Iodine is one of the leaders among vegetables [2]. Nutritional value of $100 \mathrm{~g}$ of table beet: calorie content $-42 \mathrm{kcal}$, protein content $-1,5 \mathrm{~g}$, fat $-0,1 \mathrm{~g}$, carbohydrates $-8,8 \mathrm{~g}$, food fibers (including pectin substances) $-2,5 \mathrm{~g}$, organic acids $-0.1 \mathrm{~g}$, water $-86 \mathrm{~g}$, mono- and disaccharides $-8,7 \mathrm{~g}$, starch $-0,1 \mathrm{~g}$, ash $-1 \mathrm{~g}[3]$.

In cabbage, broccoli also contain a significant amount of biologically valuable compounds - protein, pectin, vitamin C, B vitamins, and micro and macro elements. Broccoli is a low-calorie product, so this cabbage can be included in the diet of people who follow a diet for medical reasons or to maintain a healthy lifestyle [4].

Vegetable raw materials in the composition ice cream due to the moisture binding ability can prevent the formation of a defect "coarse-crystalline structure" , during hardening and storage, especially in case of violation of the temperature regimes in the freezer compartment. Vegetable raw materials contain color pigments (anthocyanins, beta-carotene, chlorophyll, etc.), are able to structure food systems [4], affect the technological processes of production, improve the organoleptic and physico-chemical characteristics of ice cream. The formation of foam structure of ice cream is a complex process, which is essentially related to the chemical composition of the product and its physical properties. Therefore, the study of the peculiarities of the formation and stabilization of the structure of ice cream with new types of plant material requires additional research [5].

In view of the above, the relevance of scientific work is to expand the range of ice cream with functional and technological and biologically complete vegetable raw materials.

The purpose of the research is to substantiate the composition and technological regimes of the production of milk-vegetable ice cream with vegetable puree on the basis of table beet and broccoli cabbage.

Main tasks of scientific work:

- Scientifically substantiate the recipe of a new type of milk ice cream with vegetable filler;

- To clarify technological regimes of production of ice cream milk-vegetable.

\section{Materials and methods}

The soft ice-cream was made with the help of a frizzer of periodic action of the brand FPM-3,5/380-50 "Elbrus-400" (manufacturer - JSC "ROSS", Ukraine). The volume of onetime pouring of the mixture into the screw chamber was $4,0 \mathrm{dm}^{3}$. The frequency of the auger 


\section{- Food Technology}

stirrer during the cooling mode (mode number 1) was $270 \mathrm{~min}^{-1}$, under the freezing mode (mode number 2) - 540 min $^{-1}$. Duration of modes №1 and №2 - 3 minutes.

The freezing and storage of ice cream were carried out in a freezer "Caravell" A/S (Denmark) at a temperature of minus $(20 \pm 2)^{\circ} \mathrm{C}$.

Sampling and preparation for analysis [6].

The cryoscopic temperature of ice cream blends was determined on a measuring complex [7]. The temperature was recorded on a personal computer using NDCONUTIL v.3xx.

Resistance to melting was determined by the time of the first drop appearance of the liquid phase and the flowing time of $10 \mathrm{~cm} 3$ of the liquid phase from the hardened ice cream sample at a temperature of $20 \pm 1{ }^{\circ} \mathrm{C}$.

The size of the air bubbles was determined by microscopy of samples using a camera Goryaeva for an increase of x150.

The overrun of soft ice cream $(\mathrm{B}, \%)$ was determined by the weight method and calculated by the formula:

$$
B=\frac{M_{1}-M_{2}}{M_{2}} \times 100
$$

where $\mathrm{M}_{1}$ - the mass of the mixture filling the glass, $\mathrm{g} ; \mathrm{M}_{2}$ - weight of ice cream filling a glass, $\mathrm{g}$.

Dynamic viscosity of the mixtures $(\mu, \mathrm{mPa} \cdot \mathrm{c})$ was determined by Geppler viscometer. The calculation of the coefficient of dynamic viscosity of the mixture $\mu(\mathrm{mPa} \cdot \mathrm{s})$ was carried out according to the formula:

$$
\mu=\mathrm{k} \times\left(\rho_{1}-\rho_{2}\right) \times \mathrm{t}
$$

where $\mathrm{k}$ is the ball constant, $\mathrm{mPa} \cdot \mathrm{cm}^{3} / \mathrm{g} ; \rho_{1}$ and $\rho_{2}$ are the density of materials of the ball and the mixture, $\mathrm{g} / \mathrm{cm}^{3} ; \mathrm{t}$ - the duration of passing the ball between the circular labels, $\mathrm{s}$.

The content of pectin in fresh and concentrated vegetable purée vegetable was determined by the calcium-pectate method [8].

For the development of milk-vegetable ice cream recipes, it was necessary to guided by regulatory requirements for its chemical composition. As a control, was produced milk ice cream with a mass fraction of fat was made at least 5\%, sugar - not less than $14,5 \%$, SZMZ - $12 \%$, dry matter - not less than $30 \%$. Normative indicators of milk-vegetable ice cream: fat $-5 \%$, sugar - not more than $10 \%$, SZMZ - 11\%, dry matter - not less than $30 \%$, dry matter of vegetable filler - not less than $4 \%$.

For use puree of beet and broccoli in composition of ice cream, according to organoleptic ally established ratio of 1:1 between it was prepared in such a way to activate the functional and technological properties of the plant filler via by hydrothermal treatment to increase the content of the soluble pectin due to partial destruction of protopectin. For this purpose the vegetables were washed, the beets were cleaned from the peel by steam, cut and chopped, stirred the mixture, heated to a temperature of $70-90{ }^{\circ} \mathrm{C}$, carry out hydrolyzation of protopectin plant tissue with citric acid at $\mathrm{pH} 2,8-3,2$ for up to 90 minutes. Hydrolyzed and boiled up to $20 \%$ of dry matter vegetable mass was cleaned and cooled in accordance with the existing method for producing pectin-containing vegetable puree [9]. Received vegetable puree are highly viscous, with time does not stratify, it has a bright cherry color and a pleasant sweet flavor. 
Experimental samples of ice cream were obtained according to the following scheme: preparation of milk mixture $\left(40-45^{\circ} \mathrm{C}\right)$; preparation of vegetable filler (cutting and blanching of vegetables, rubbing, heat treatment at $80-85^{\circ} \mathrm{C}$ for 20 minutes), mixing of milk mix and vegetable filler $\left(40-45^{\circ} \mathrm{C}\right)$; filtering milk-vegetable mixture; pasteurization of the mixture $\left(83-87^{\circ} \mathrm{C}, 2-3 \mathrm{~min}\right)$; homogenization of the mixture $\left(12-15 \mathrm{MPa}, 80-85^{\circ} \mathrm{C}\right)$; cooling and maturation of the mixture $\left(0-6^{\circ} \mathrm{C}\right)$; freeze of the mixture; dosing and forming portions of soft ice cream; hardening of ice cream (from -20 to $-25^{\circ} \mathrm{C}$ ) [10].

\section{Results and discussion}

In the first stage, the distribution of pectin substances in vegetable puree was investigated before and after hydrothermal treatment under the above conditions.

The mass fraction of dry matter (DM), pectin substances (PS), soluble pectin (SP), protopectin (PP) of fresh and heat-treated puree from beet and broccoli for ratio 1:1, as well as the mass fraction of SB from the content of PP in percentages are shown in the table. 1

Table 1

Content and distribution of pectin substances in vegetable puree of different degree of processing $(\mathbf{P} \geq \mathbf{0 , 9 5} ; \mathbf{n = 3})$

\begin{tabular}{|l|c|c|c|c|c|}
\hline $\begin{array}{c}\text { Kind of raw } \\
\text { material }\end{array}$ & $\begin{array}{c}\text { Mass } \\
\text { fraction of } \\
\text { DM,\% }\end{array}$ & $\begin{array}{c}\text { Mass fraction } \\
\text { of PS, \%/ 100 } \\
\text { g puree }\end{array}$ & $\begin{array}{c}\text { Mass } \\
\text { fraction of } \\
\text { SP, } \%\end{array}$ & $\begin{array}{c}\text { Mass } \\
\text { fraction of } \\
\text { PP, } \%\end{array}$ & $\begin{array}{c}\text { Contents } \\
\text { of SP,\%, } \\
\text { from PS }\end{array}$ \\
\hline Fresh puree & $13,37 \pm 0,67$ & $1,88 \pm 0,07$ & $0,71 \pm 0,02$ & $1,17 \pm 0,04$ & $37,77 \pm 1,05$ \\
\hline $\begin{array}{l}\text { Activated } \\
\text { puree }\end{array}$ & $20,07 \pm 0,93$ & $2,80 \pm 0,10$ & $2,10 \pm 0,09$ & $0,70 \pm 0,01$ & $75,00 \pm 2,36$ \\
\hline
\end{tabular}

According to the results of the study, given in Table 1, the expediency of thermoacid processing of vegetable puree is understandable, due to which the increased content of SP will activate the technological properties of vegetable filler. Significant change in the ratio between the SP and the PP (from 1,65 to 0,33) in the direction of increasing the content of SP and the corresponding concentration of dry matter of vegetables to $20 \%$ makes it possible to replace part of the blend of ice cream with a mass fraction of dry matter about $30 \%$ without a significant change of balance for this indicator.

The thermoacid degradation of PP, which results in an elevated SP content, can provide vegetable filler with additional water-binding and structuring ability and shorten the maturing time of the blends. Therefore, at the next stage of the study, the rational regimes of maturation of fresh and activated vegetable puree were determined, compared to the control sample of a blend containing $0,5 \%$ of stabilizer (guar gum), with the most significant characteristic - the coefficient of dynamic viscosity.

The mass fraction of vegetable puree was given arbitrarily, at the level of $10 \%$, according to typical recipes of ice cream with vegetable fillers (from 10 to $15 \%$ ). To determine the possibility of a partial replacement of the stabilizer with the technologically activated vegetable filler, milk-vegetable samples of blends were prepared with a half the content of the stabilizer of the structure (Figure 1). Since the recommended values of the coefficient of dynamic viscosity of mixtures of milk ice cream are those that are not lower than $140 \mathrm{mPa} \cdot \mathrm{s}$ [11], this is the minimum allowable value chosen as a criterion for the effectiveness of blends structuring. 


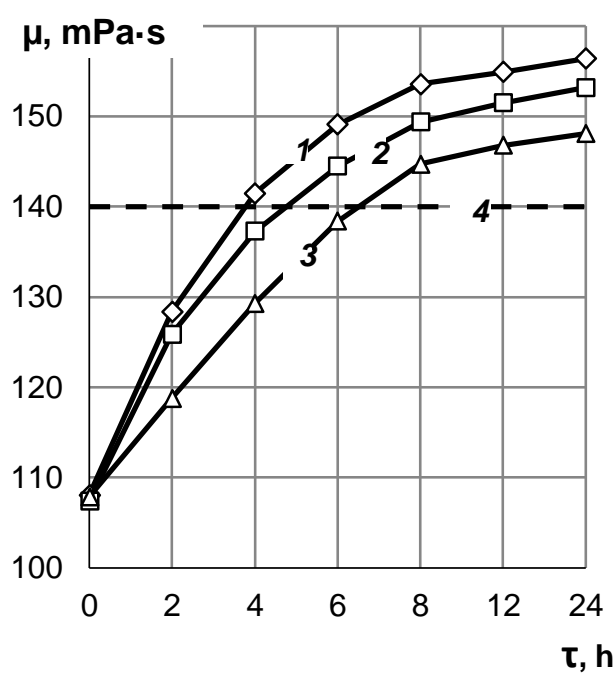

$a$

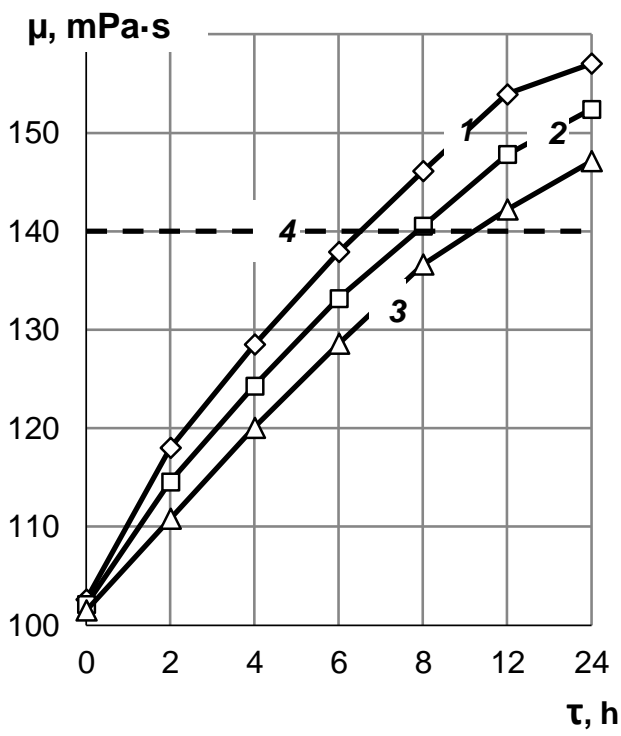

$c$

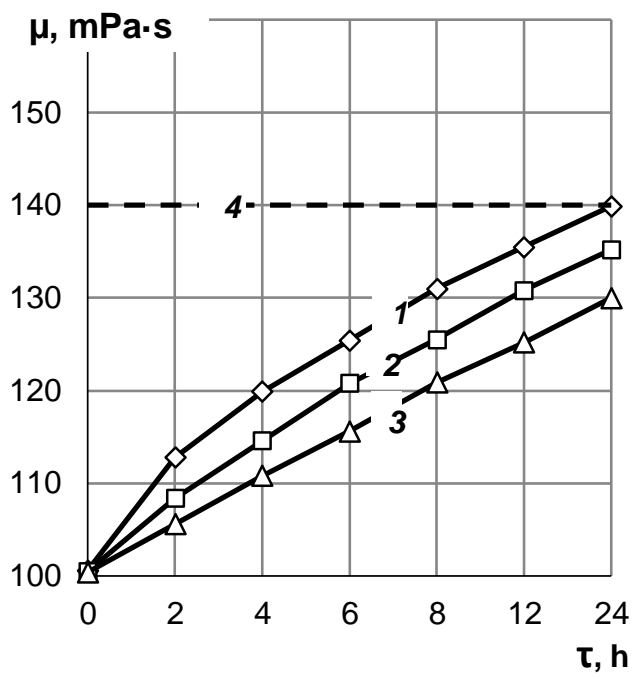

$b$

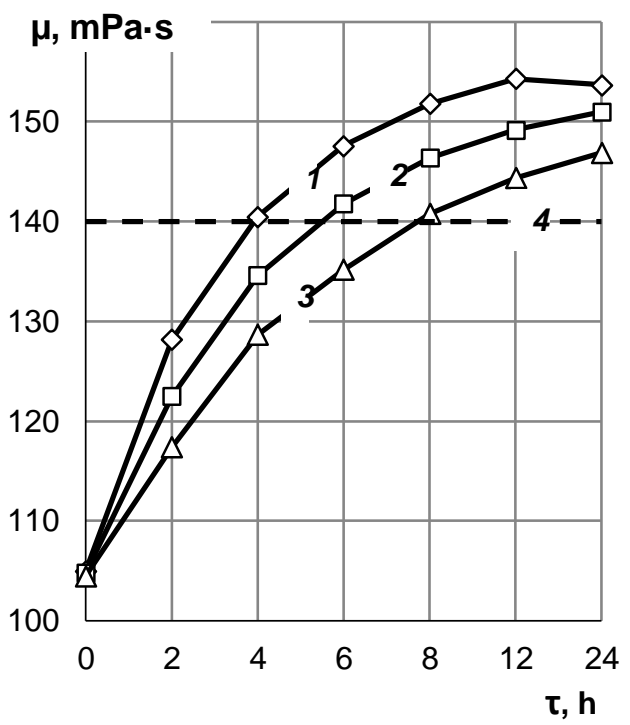

$d$

Figure 1. Effect of the maturing time $(\tau)$ on the coefficient of dynamic viscosity $(\mu)$ of ice cream blends:

$a$ - milk with $0.5 \%$ stabilizer (control);

$b$ - milk with $10 \%$ fresh puree without stabilizer;

$c$ - milk with $10 \%$ fresh puree and $0,25 \%$ stabilizer;

$d$ - milk with $10 \%$ activated puree and $0,25 \%$ stabilizer

Temperature of blend, ${ }^{\circ} \mathrm{C}: 1-0 ; 2-4 ; 3-6$.

4 - the minimum value of dynamic viscosity 
As can be seen from Figure 1, achieving lowest purposeful amount of dynamic viscosity coefficient at a temperature of $0^{\circ} \mathrm{C}$ to control observed through 4 hours, for milk with fresh vegetable puree and $0,25 \%$ stabilizer - in 8 hours, and for milk with vegetable concentrated puree and 0,25\% stabilizer - after 6 hours. At the same time, a mixture of milk ice cream with fresh puree without stabilizer acquires the required viscosity at the lowest maturation temperature $\left(0{ }^{\circ} \mathrm{C}\right)$ only after 24 hours [12]. This confirms the need to introduce into the composition of blend a stabilizer of structure or vegetable puree with high content of SP, or combining them. Thus, it is possible to use vegetable paste with a high content of SP at the simultaneous $50 \%$ replacing of structure stabilizer in blends at the expense of pectin stabilizing action in the composition of vegetables.

To justify rational content vegetable paste in milk ice cream at the next stage of the study determined cryoscopic temperature $\left(\mathrm{t}_{\mathrm{cr}}\right)$ of milk-vegetables blends, which contain from 5 to $20 \%$ activated filler. This $t_{\mathrm{cr}}$ affects the proportion of bound water, what causing the formation of creamy consistency of the finished product after the hardening process and regimes of freezing in the technological cycle of production of ice cream.

Experimentally set values $\mathrm{t}_{\mathrm{cr} \cdot \mathrm{m}}$ of ice cream blends of traditional composition and milkvegetable were compared with the data obtained by calculating the depression of freezing temperature of the studied mixtures according to sucrose equivalent tcr.c $[13,14]$. Chemical composition and tcr. of ice cream blends with a mass fraction of fat $5 \%$ and a mass fraction of sugar $15,5 \%$ for various ratios between milk and vegetable bases are shown in Table 2 . Mass fraction of stabilizer were changed proportionally to activated puree and at achievements of mass fraction of soluble pectin $0,4 \%$ in the paste composition completely excluded the stabilizer from formulation.

Table 2

Chemical composition and cryoscopic temperature of ice cream blends with different contents of vegetable puree

\begin{tabular}{|c|c|c|c|c|c|c|}
\hline \multirow{2}{*}{$\begin{array}{l}\text { Milk Ice Cream } \\
\text { (mass fraction of } \\
\text { fat } 5 \% \text {; mass } \\
\text { fraction of sugar } \\
15,5 \% \text { ) }\end{array}$} & \multicolumn{5}{|c|}{ Composition of the blend, $\%$} & \multirow[b]{2}{*}{$\mathrm{t}_{\text {cr.m }} / \mathrm{t}_{\text {cr.c }} / \Delta \mathrm{t},{ }^{\circ} \mathrm{C}$} \\
\hline & DNDR & Stabilizer & Water & $\begin{array}{c}\text { DM of } \\
\text { vegetables }\end{array}$ & SP & \\
\hline Control & 10,0 & 0,50 & 69,0 & - & - & $-2,51 /-2,18 / 0,33$ \\
\hline $5 \%$ puree & 9,5 & 0,38 & 68,62 & 1,0 & 0,105 & $-2,56 /-2,18 / 0,38$ \\
\hline $10 \%$ puree & 9,0 & 0,25 & 68,25 & 2,0 & 0,210 & $-2,59 /-2,18 / 0,41$ \\
\hline $15 \%$ puree & 8,5 & 0,13 & 67,87 & 3,0 & 0,315 & $-2,62 /-2,17 / 0,45$ \\
\hline $20 \%$ puree & 8,0 & 0 & 67,50 & 4,0 & 0,420 & $-2,64 /-2,16 / 0,48$ \\
\hline
\end{tabular}

According to the analysis of the chemical composition of all samples, a slight change in the dry matter content in ice cream (from 69 to $67,5 \%$ ) should be noted, even with a maximum $20 \%$ replacement of the milk blend in vegetable puree. That is, the balance of dry matter in the mixtures is practically preserved in the established range of changes in the content of vegetable paste.

Despite the slight increase in water content in ice cream during increasing the amount of vegetable puree, there is a slight decrease in the cryoscopic temperature from minus 2,51 to minus $2,64{ }^{\circ} \mathrm{C}$. Moreover, the difference between measured and calculated values of this indicator increases. This effect can be explained, first of all, by the extremely high waterbinding ability of the soluble pectin, which significantly reduces the free water content of the 
blends, thereby increasing the concentration of solutions of single, double carbohydrates and salts in its residue. In vegetable raw materials also are contained about 5-6\%. monosaccharides and disaccharides, which partially replenish the lactose deficiency in reducing the content of milk components in milk-vegetable blends. Thus, partial replacement of the milk blend in vegetable puree in the studied range will not cause deterioration of the physical and chemical indicators of ice cream quality and will not significantly affect the technological parameters of its production. Taking into consideration the above, the introduction of a new type of ice cream with vegetable puree will not require the technical re-equipment of the existing production provided the vegetable component is delivered on request from the canning industry enterprises.

At the next stage, physicochemical indicators of milk ice cream with vegetable paste were studied (Table 3, Table 4).

Physico-chemical parameters of milk ice cream with vegetable paste $(P \geq 0.95 ; n=3)$

Table 3

\begin{tabular}{|l|c|c|c|c|c|}
\hline \multirow{2}{*}{ Indicator } & \multicolumn{5}{|c|}{ Mass fraction of vegetable paste, \% } \\
\cline { 2 - 6 } & 0 & 5 & 10 & 15 & 20 \\
\hline Overrun,\% & $75,0 \pm 1,5$ & $73,0 \pm 1,6$ & $72,0 \pm 1,6$ & $70,0 \pm 1,6$ & $65,0 \pm 1,6$ \\
\hline $\begin{array}{l}\text { Resistance to } \\
\text { melting, min }\end{array}$ & $48,2 \pm 1,1$ & $46,5 \pm 0,9$ & $45,0 \pm 0,9$ & $44,0 \pm 0$, & $43,0 \pm 0,9$ \\
\hline $\begin{array}{l}\text { Average diameter } \\
\text { of air bubbles, } \\
\text { mcm }\end{array}$ & $47,6 \pm 0,4$ & $46,0 \pm 0,4$ & $45,5 \pm 0,4$ & $43,7 \pm 0,4$ & $40,2 \pm 0,4$ \\
\hline $\begin{array}{l}\text { The temperature of } \\
\text { the soft ice-cream } \\
\text { on the exit from the } \\
\text { freezer, }{ }^{\circ} \mathrm{C}\end{array}$ & $-3,5 \pm 0,1$ & $-3,5 \pm 0,1$ & $-3,5 \pm 0,1$ & $-3,4 \pm 0,1$ & $-3,3 \pm 0,1$ \\
\hline
\end{tabular}

Quality indicators of milk ice cream and milk-vegetable

Table 4

\begin{tabular}{|c|c|c|c|c|c|}
\hline Indicator & \multicolumn{5}{|c|}{ Mass fraction of vegetable paste, $\%$} \\
\hline & 0 & 5 & 10 & 15 & 20 \\
\hline Appearance & \multicolumn{5}{|c|}{ Homogeneous mass with high ability to formation } \\
\hline $\begin{array}{l}\text { Structure } \\
\text { and } \\
\text { consistency }\end{array}$ & \multicolumn{2}{|c|}{$\begin{array}{l}\text { Homogeneous, slightly snowy } \\
\text { consistency }\end{array}$} & \multicolumn{2}{|c|}{$\begin{array}{l}\text { Homogeneous, } \\
\text { plastic, creamy }\end{array}$} & $\begin{array}{l}\text { Homogeneous, } \\
\text { too soft, creamy }\end{array}$ \\
\hline $\begin{array}{l}\text { Taste and } \\
\text { smell }\end{array}$ & $\begin{array}{l}\text { Pure, } \\
\text { characteristic for } \\
\text { milk ice cream, } \\
\text { without foreign } \\
\text { flavors and odors }\end{array}$ & $\begin{array}{l}\text { Pure, } \\
\text { characteristic for } \\
\text { milk ice cream, } \\
\text { with barely } \\
\text { noticeable taste of } \\
\text { vegetable filler }\end{array}$ & $\begin{array}{l}\text { Pure, } \\
\text { for mi } \\
\text { with a } \\
\text { flavor } \\
\text { paste }\end{array}$ & $\begin{array}{l}\text { eristic } \\
\text { ream, } \\
\text { nt } \\
\text { etable }\end{array}$ & $\begin{array}{l}\text { Pure, with too } \\
\text { much flavor of } \\
\text { vegetables }\end{array}$ \\
\hline Color & $\begin{array}{l}\text { White, uniform in } \\
\text { mass }\end{array}$ & $\begin{array}{l}\text { Weak pronounced } \\
\text { pink tint }\end{array}$ & $\begin{array}{l}\text { Mode } \\
\text { unifor } \\
\text { masse }\end{array}$ & & $\begin{array}{l}\text { Dark pink, } \\
\text { uniform in all } \\
\text { masses }\end{array}$ \\
\hline
\end{tabular}


In the specified range of content, vegetable filler improves the ability to form ice cream, its consistency, resistance to melting, as well as the dispersion of the air phase. Ice cream with vegetable puree is pleasant pink color and plastic consistency. The overrun of ice cream with vegetable raw material practically does not differ from the control sample and corresponds to the recommended value (not less than 60\%).

The prospect of further research is to study the influence of vegetable puree in the specified range of content on the quality of ice cream during storage.

\section{Conclusions}

1. New recipes of milk ice cream with vegetable puree from broccoli and table beet (for a ratio of $1: 1$ ) in the amount of 10 to $15 \%$ were developed, which ensures high quality of the finished product.

2. According to the values of the cryoscopic temperature of ice cream blends with vegetable puree, the possibility of ice cream production under the generally accepted modes of processing was confirmed.

3. According to the values of the coefficient of dynamic viscosity rational regimes of maturation of milk-vegetable mixtures are substantiated: at a temperature of $0-4{ }^{\circ} \mathrm{C}-$ up to 6 hours; for $6^{\circ} \mathrm{C}-$ up to 8 hours.

4. The implementation of a new type of ice cream with vegetable puree does not require the technical re-equipment of existing production and will contribute to the expansion of the range of domestic ice cream of high nutritional value.

\section{References}

1. Turchin I., Slivka NB, Melnyk O.R., Kopach V. (2013), Use of nonconventional components in ice cream technology, Ecotrophology. Progress, problems, prospects of environmentally safe production. Materials IV International scientific-practical conference devoted to the 10th anniversary of the Department of Ecotrophology, BNAU, pp. 92-93.

2. Shaiko T.V. (2015), Beet Pasta - A promising direction of extension of the range of food products, Food resources. Series: Technical Sciences, 4, pp. 7-10.

3. Brovenko T., (2016), Culinary use of table beets, Food industry of agrarian and industrial complex, 1-2, pp. 39-42.

4. Didi O., (2016), Yield and quality of broccoli cabbage hybrids in the Western Foreststeppe of Ukraine, Visnyk of Lviv National Agrarian University. Series: Agronomy, No. 20, pp. 98-102.

5. Martich V.V., Polischuk G.E., Serbova M.I., (2013), Research of Wheat Germ Foaming Capacity in Dairy Ice-Cream Composition, Nauka ta Innovacii, 9(5), pp. 10-16.

6. Marshall R. T., Goff H. D., Hartel R. W., (2013), Ice cream, Springer US, New York.

7. Potapov SG, Maslikov MM (2009), Laboratory Installation for Continuous Monitoring and Registration of Gas Environment Parameters, NUHT Scientific Papers, 29, pp. 7880 .

8. Zgursky A., Polischuk G., Krapivnytska I., (2011), Redistribution of pectin substances in vegetable raw materials in the production of ice cream, Food industry, №10, pp. 5055 .

9. Hartel R.W. (2010), Mechanisms of Ice Crystallization in Ice Cream Production, Comprehensive reviews in food science and food safety, 9(2), pp. 213-222 
10. Kosoy V. L., Dunchenko NN, Egorov AV (2008), Engineering Rheology in Ice Cream Production, DeLi Prints, Moscow.

11. Christiaens S., Mbong V. B., Buggenhout S.V., David C. C., Hofkens J., Hendrickx M.E., (2012), Influence of processing on the pectin structure-function relationship in broccoli purée, Innovative Food Science \& Emerging Technologies, №15, pp. 57-65.

12. Guldiken B., Gamze Toydemir G., Memis K. N., Okur S., Boyacioglu D., Capanoglu E., (2016), Home-Processed Red Beetroot (Beta vulgaris L.) Products: Changes in Antioxidant Properties and Bioaccessibility, International journal of molecular sciences, 17(6), pp. 858.

13. Bahramparvar V., Tehrani M. M., (2011), Application and Functions of Stabilizers in Ice Cream, Food Reviews International, 27(4), pp. 389-407.

14. Polischuk GE, Semko T.V., (2012), Investigation of the water phase of mixtures and ice cream with natural structuring components, Collection of scientific works of Vinnytsia National Agrarian University, 2(1), pp. 109-116. 